\title{
Flower Initiation and Tassel Emergence in Sugarcane
}

\author{
Teh-ling Chu and J. L. Serapión ${ }^{1}$
}

INTRODUCTION

The flowering process in sugarcane is extremely sensitive to environment. A variety flowering heavily one year may not flower in another. The response of the flowering process to environment, moreover, varies considerably among varieties. Increased knowledge of some of the factors involved in sugarcane flowering has resulted in new techniques which can be employed to control flowering by cane breeders and growers alike. This knowledge, however, is still far from complete because important factors involved in sugarcane flowering remain obscure.

Burr et al. $(1)^{2}$ and Coleman (4) claim all of the so-called early- and late-flowering varieties of sugarcane may initiate primordia on the same date. Time of flower emergence bears little relation to time of initiation. The differing rates of flower emergence are varietal characteristics. Vijayasaradhy and Narasimhan (14) reported the time of primordia initiation to be essentially the same for both early-and late-flowering varieties, and that differences in flower emergence relate to variable growth and development rates. However, Panje and Srinivasan (10) concluded from observations on various forms of Saccharum sponlaneum $\mathrm{L}$. that floral initiation is not simultaneous in all clones. The time of initiation was correlated with time of flowering. Observations by Clements and Awad (3) and Stevenson (18) were consistent with Panje's viewpoint. Paliatseas and Chilton (9) reported that the emergence of sugarcane inflorescence was controlled by several environmental conditions of which temperature, light intensity, and light quality were the most important.

The studies presented herein were designed to determine (a) the time at which the vegetative meristem is transformed into a flower primordium, (b) whether all varieties initiate a flower primordium at the same time and (c) to further our knowledge of the environmental conditions affecting time of flower initiation and tassel emergence.

1 Plant Breeder and Assistant Agronomist, respectively, Gurabo Substation, Agricultural Experiment Station Mayagïez Campus, University of Puerto Rico, Río Piedras, P.R.

The authors wish to express their gratitude to Dr. M. A. Tió, Phytophysiologist of the Department of Phytopathology and Botany, for demonstrating the dissecting technique employed during this research.

2Italic numbers in parentheses refer to Literature Cited, p. 112-13. 


\section{MATERIALS AND METHODS}

Our studies were conducted at the Gurabo Agricultural Experiment Substation situated at latitude $18^{\circ} 16^{\prime} \mathrm{N}$. in the humid region of Puerto Rico. A total of 78 varieties were employed in the experiments during the flowering induction periods of 1967 and 1969. They were planted in early February on the slope of a small hill at an elevation of around 250 to 300 feet above sea level. Both plant and ratoon canes were managed in like manner. Stem apices of three, large, vigorous stalks of each variety were sampled daily beginning September 1. They were dissected and examined under the microscope for flower primordia. The date of flower initiation and emergence of the first tassel within each variety was recorded.

Two methods have been developed for measuring flower initiation or the appearance of flower primordia. Salisbury (12) and Lincoln et al. (8) developed the stage method in Xanthium. In essence this method determines the developmental condition of the flower by microscopic examination. It is, in other words, a method for quantitative measurement of the flowering response. Another method is the leaf or node index system which was first used systematically by Purvis (11) in rye and by Clements et al. (S) in sugarcane. This method is based upon the expectation that no more leaves will be produced after the meristem is transformed from a vegetative to a reproductive structure. Although the leaf index method is regarded as the most reliable measure of flower initiation $(7,3)$, the results are not known until after the inflorescence has emerged. To save time and to reduce the work load, the stage method was perfected to measure floral initiation in sugarcane, in accordance with the technical definitions given in the following tabulation and in figure 1.

Characteristics

0 Vegetative growing point, relatively flat and small. It is rat her difficult at this stage to remove the last leaf from the growing point.

1 Clearly visible swelling of the growing point, constricted at the base, surrounding mantle of meristematic cells becoming little harder, few bracts or individual flower primordia observed. At this stage the last leaf is removed more easily.

2 Inflorescence primordia becoming taller, more constricted at the base, more bracts developed.

3 Inflorescence primordia taller, entirely covered with bracts, milk white in color.

In accordance with the results of thousands of microscopic examinations performed during this study, it is concluded that differences in the time of flower initiation by different varieties can be determined accurately by this method. 


\section{RESULTS AND DISCUSSION}

TIME OF FLOWER INITLATION AND TASSEL EMERGENCE

From the data shown in tables 1,2 and 3 it is evident that a wide divergence existed in flower initiation by the 78 varieties studied in two flowering seasons. The earliest and latest dates of flower initiation were September 3 to 5 (for C.B. 41227 and N.Co. 310) and October 1 to 6 (for Cl. 41-223 and

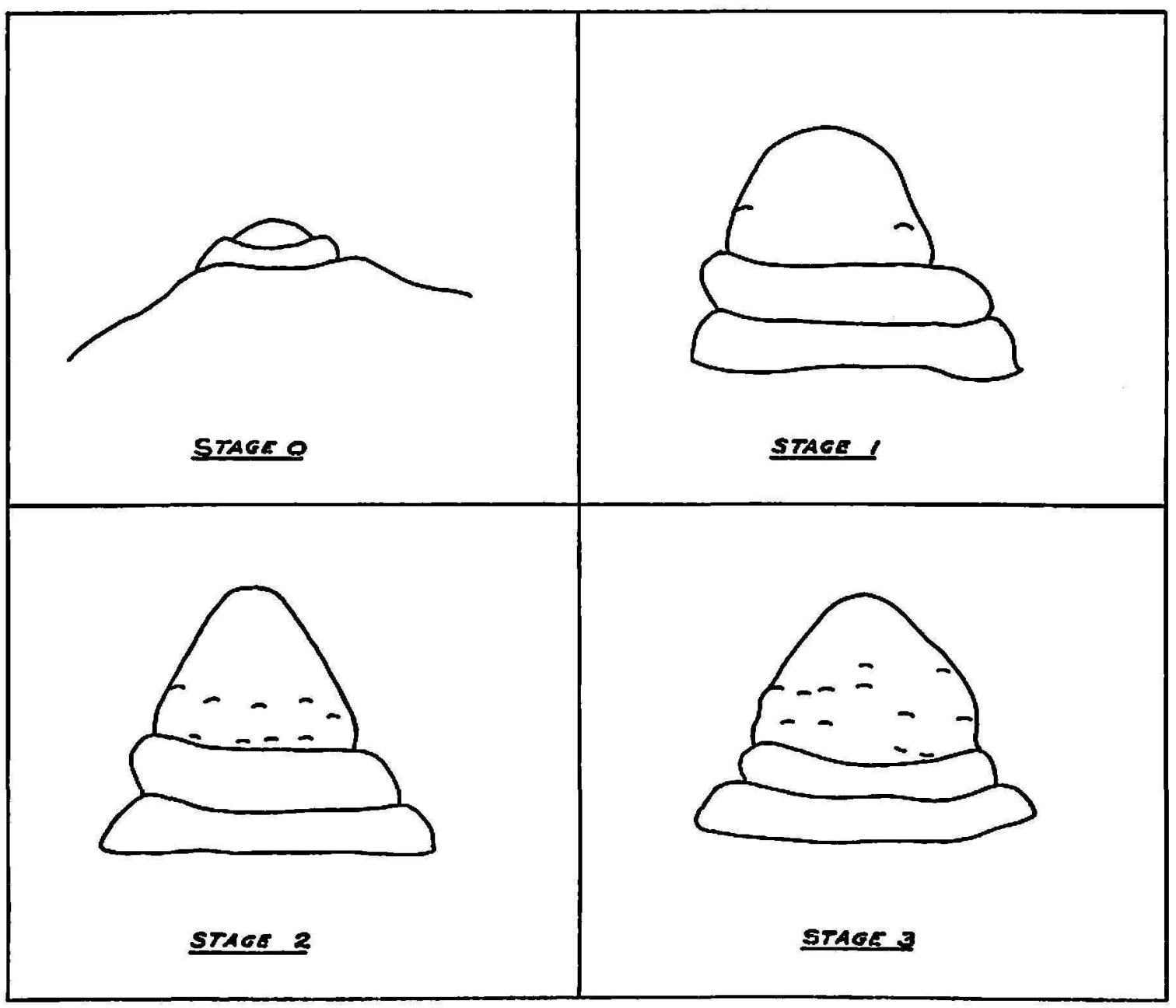

Fra. 1-The different stages of flower initiation in sugarcane.

B.0. 17), respectively. The time of flower initiation therefore extended over a period of about 1 month.

Tables 1 and 3 also indicate that the time of flower initiation is closely related to the time of flowering as far as the early-and late-initiating varieties are concerned. Among intermediate varieties (table 2) the time of tassel emergence appeared to differ greatly with respect to variety and flowering season. This signifies that the speed of development and elongation of inflorescence plays an important role in determining the flowering time of different varieties. 
The pattern and degree of constancy in the time of flower initiation is presented graphically in figures 2 and 3 . Figure 2 indicates that there is no substantial difference in the time pattern of flower initiation. Of the varieties studied, 64.6 percent initiated primordia in 1967 and 72.5 percent in 1969, during the period September 13 to September 22.

As shown in figure 3 , it is also evident that the time of flower initiation within the respective varieties is fairly constant from one year to the next. Ninety percent of the varieties showed a deviation of 0 to 5 days in the time of initiation during the 2-year period. Varieties having a deviation of only

TABLE 1.-The time of flower initiation and tassel emergence of the early-initiating varielies

\begin{tabular}{|c|c|c|c|c|c|c|c|}
\hline \multirow[b]{3}{*}{ Variely } & \multicolumn{6}{|c|}{ Pear } & \multirow{3}{*}{$\begin{array}{c}\text { Dayss } \\
\text { required } \\
\text { for emer } \\
\text { gence of } \\
\text { tassel }\end{array}$} \\
\hline & \multicolumn{3}{|c|}{1967} & \multicolumn{3}{|c|}{1969} & \\
\hline & $\begin{array}{l}\text { Dale of flower } \\
\text { initialion }\end{array}$ & $\begin{array}{l}\text { Dale of first } \\
\text { tassel lip } \\
\text { emergence }\end{array}$ & $\begin{array}{c}\text { Days } \\
\text { required } \\
\text { for emer- } \\
\text { gence of } \\
\text { lassel }\end{array}$ & $\begin{array}{c}\text { Dale of fower } \\
\text { inilialion }\end{array}$ & $\begin{array}{l}\text { Date of first } \\
\text { lassel iip } \\
\text { emergence }\end{array}$ & $\begin{array}{c}\text { Dayys } \\
\text { requitred } \\
\text { for emer- } \\
\text { gencecof of } \\
\text { lassel }\end{array}$ & \\
\hline & & & & & & & Aoerage \\
\hline B. 35207 & Sept. 6 & Nov. 8 & 64 & Sept. 6 & Nov. 6 & 62 & 63.0 \\
\hline B. 41227 & Sept. 5 & Nov. 4 & 61 & Sept. 3 & Nov. 6 & 65 & 63.0 \\
\hline Co. 312 & Sept. 14 & Nov. 9 & 57 & Sept. 10 & Nov. 3 & 55 & 56.0 \\
\hline Co. 453 & Sept. 14 & Nov. 4 & 52 & Sept. 12 & Oct. 28 & 47 & 49.5 \\
\hline Co. 449 & Sept. 12 & Nov. 17 & 67 & Sept. 12 & Nov. 2 & 52 & 59.5 \\
\hline Co.K. 32 & Sept. 15 & Nov. 4 & 51 & Sept. 13 & Nov. 3 & 52 & 51.5 \\
\hline F. 144 & Sept. 14 & Nov. 7 & 55 & Sept. 13 & Nov. 1 & 50 & 52.5 \\
\hline M. 336 & Sept. 13 & Nov. 19 & 68 & Sept. 13 & Nov. 17 & 66 & 67.0 \\
\hline N.Co. 310 & Sept. 5 & Oct. 30 & 56 & Sept. 4 & Oct. 26 & 53 & 54.5 \\
\hline N.Co. 334 & Sept. 12 & Nov. 5 & 55 & Sept. 12 & Oct. 30 & 49 & 52.0 \\
\hline P.O.J. 2878 & - & - & - & Sept. 12 & Nov. 5 & 55 & - \\
\hline
\end{tabular}

0 to 2 days in the time of initiation still account for 52.9 percent. This evidently indicates that flower initiation in sugarcane, like any other physiological process, is determined by the genotype and specific environmental conditions.

In view of the fact that the earliest flower primordia appeared September 3 , and initiation within all varieties (with few exceptions) was completed by the end of September, the inductive photoperiod in Puerto Rico (latitude $18^{\circ} \mathrm{N}$ ) appears to range from September 1 to September 30. A 12-hour, 29-minute day occurs on September 1, and a 12-hour day on September 30. However, since a majority of varieties initiated flowering during the period of September 13 (12 hours, 17 minutes) to September 22 (12 hours, 7 minutes), the model day-length for floral initiation appears to be 12 hours, 
TABLE 2.-The time of flower initiation and tassel emergence of the intermediate-initiating varieties

\begin{tabular}{|c|c|c|c|c|c|c|c|}
\hline \multirow[b]{3}{*}{ Variely } & \multicolumn{6}{|c|}{ Year } & \multirow{3}{*}{$\begin{array}{l}\text { Days required } \\
\text { for emergemec } \\
\text { of tassel }\end{array}$} \\
\hline & \multicolumn{3}{|c|}{1967} & \multicolumn{3}{|c|}{1969} & \\
\hline & $\begin{array}{l}\text { Dale of forper } \\
\text { initialion }\end{array}$ & $\begin{array}{c}\text { Date of first } \\
\text { lassel tip } \\
\text { emergence }\end{array}$ & $\begin{array}{l}\text { Days ree } \\
\text { quired for } \\
\text { emergence } \\
\text { of tassel }\end{array}$ & $\begin{array}{l}\text { Dafe of foroer } \\
\text { iniliation }\end{array}$ & $\begin{array}{l}\text { Date of first } \\
\text { lassel lip } \\
\text { emergence }\end{array}$ & $\begin{array}{l}\text { Days re } \\
\text { quired for } \\
\text { emergence } \\
\text { of lassel }\end{array}$ & \\
\hline & & & & & & & Average \\
\hline B. 4145 & Sept. 18 & Dec. 5 & 79 & Sept. 20 & Dec. 5 & 77 & 78.0 \\
\hline B. 47258 & Sept. 17 & Nov. 25 & 70 & Sept. 15 & Dec. 2 & 79 & 74.5 \\
\hline B.0. 11 & Sept. 19 & Nov. 16 & 59 & Sept. 18 & Nov. 16 & 60 & 59.5 \\
\hline C.B. $46-44$ & Sept. 21 & Nov. 16 & 67 & Sept. 21 & Nov. 13 & 54 & 60.5 \\
\hline Co. 281 & - & - & - & Sept. 22 & Nov. 14 & 54 & - \\
\hline Co. 301 & Sept. 21 & Nov. 24 & 65 & Sept. 18 & Nov. 11 & 55 & 60.0 \\
\hline Co. 527 & Sept. 17 & Nov. 16 & 61 & Sept. 14 & Nov. 1 & 49 & 55.0 \\
\hline Co. 658 & Sept. 25 & Nov. 27 & 64 & Sept. 22 & Nov. 7 & 47 & $\mathbf{5 5 . 5}$ \\
\hline Co. 740 & Sept. 21 & Nov. 26 & 67 & Sept. 24 & Nov. 28 & 66 & 66.5 \\
\hline Сo. 775 & Sept. 23 & Nov. 27 & 66 & Sept. 22 & Nov. 7 & 47 & 56.5 \\
\hline Co.L. 9 & Sept. 16 & Nov. 16 & 62 & Sept. 16 & Nov. 8 & 54 & 58.0 \\
\hline Co.S. 245 & Sept. 20 & Nov. 17 & 59 & Sept. 18 & Nov. 13 & 57 & 58.0 \\
\hline C.P. $34-120$ & Sept. 18 & Nov. 10 & 54 & Sept. 22 & Nov. 4 & 44 & 49.0 \\
\hline C.P. 36-105 & Sept. 15 & Nov. 11 & 58 & Sept. 15 & Nov. 2 & 49 & 53.5 \\
\hline C.P. $48-103$ & Sept. 18 & Nov. 10 & 54 & Sept. 15 & Nov. 3 & 50 & 52.0 \\
\hline C.P. $50-28$ & Sept. 16 & Nov. 11 & 57 & Sept. 19 & Nov. 5 & 48 & 52.5 \\
\hline C.P. 52-1 & Sept. 16 & Nov. 9 & 55 & Sept. 16 & Nov. 1 & 47 & 51.0 \\
\hline C.P. 52-43 & - & - & - & Sept. 21 & Nov. 9 & 50 & - \\
\hline F. 138 & Sept. 23 & Nov. 18 & 57 & Sept. 24 & Nov. 15 & 53 & 55.0 \\
\hline F. 141 & Sept. 26 & Nov. 25 & 61 & Sept. 20 & Nov. 10 & 52 & 56.5 \\
\hline F. 142 & - & - & - & Sept. 20 & Nov. 2 & 44 & 一 \\
\hline H. 32-8560 & None & - & - & Sept. 21 & Nov. 23 & 64 & 一 \\
\hline M. 253/48 & Sept. 20 & Nov. 18 & 60 & Sept. 20 & Nov. 12 & 54 & 57.0 \\
\hline N.Co. 292 & Sept. 18 & Nov. 18 & 62 & Sept. 15 & Nov. 4 & 51 & 56.5 \\
\hline N.Co. 293 & Sept. 17 & Nov. 5 & 50 & Sept. 13 & Nov. 2 & 51 & 50.5 \\
\hline N.Co. 349 & Sept. 17 & Nov. 15 & 60 & Sept. 15 & Nov. 3 & 50 & 55.0 \\
\hline N.Co. 376 & Sept. 19 & Nov. 15 & 58 & Sept. 16 & Nov. 3 & 49 & 53.5 \\
\hline N.Co. 382 & Sept. 20 & Nov. 6 & 48 & Sept. 15 & Nov. 3 & 50 & 49.0 \\
\hline P.R. 980 & Sept. 15 & Nov. 24 & 71 & Sept. 15 & Nov. 13 & 60 & 65.5 \\
\hline P.R. 1013 & Sept. 17 & Nov. 18 & 63 & Sept. 14 & Nov. 8 & 56 & 59.5 \\
\hline P.R. 1028 & - & 一 & - & Sept. 17 & Nov. 5 & 50 & - \\
\hline P.R. 1039 & Sept. 19 & Nov. 30 & 73 & Sept. 22 & Nov. 25 & 65 & 69.0 \\
\hline P.R. 1049 & Sept. 18 & Nov. 18 & 62 & Sept. 13 & Nov. 3 & 52 & $\mathbf{5 7 . 0}$ \\
\hline P.R. 1085 & None & - & - & Sept. 23 & Jan. 3/70 & 103 & - \\
\hline P.R. 1111 & Sept. 15 & Nov. 16 & 63 & Sept. 16 & Nov. 1 & 47 & 55.0 \\
\hline P.R. 1117 & Sept. 20 & Nov. 20 & 62 & Sept. 20 & Nov. 10 & 52 & 57.0 \\
\hline P.T. 43-52 & - & - & - & Sept. 21 & Nov. 29 & 70 & - \\
\hline Q. 55 & Sept. 27 & Nov. 26 & 61 & Sept. 22 & Nov. 16 & 56 & 58.5 \\
\hline Q. 68 & Sept. 19 & Nov. 10 & 53 & Sept. 18 & Nov. 15 & 59 & 56.0 \\
\hline Q. 69 & Sept. 27 & Nov. 15 & 50 & Sept. 21 & Nov. 3 & 44 & 47.0 \\
\hline Q. 72 & Sept. 23 & Dec. 2 & 71 & Sept. 20 & Nov. 20 & 62 & 66.5 \\
\hline Tuc. 2645 & Sept. 22 & Nov. 12 & 52 & Sept. 15 & Nov. 3 & 50 & 51.0 \\
\hline Tuc. 2683 & Sept. 23 & Nov. 3 & 42 & Sept. 14 & Oct. 26 & 43 & 42.5 \\
\hline
\end{tabular}

1 The final observation was made on October 6, 1967. 
7 to 17 minutes. In Hawaii (latitude $19^{\circ}$ to $22^{\circ} \mathrm{N}$ ) the approximate date on which initiation begins is around September 2, a 12.5-hour day (1). The inductive photoperiod in Hawaii was reported to be from September 1 to September $20(6)$.

TABLE 3.-The time of flower initiation and tassel emergence of the late-initiating varieties

\begin{tabular}{|c|c|c|c|c|c|c|c|}
\hline \multirow[b]{3}{*}{ Variely } & \multicolumn{6}{|c|}{ Year } & \multirow{3}{*}{$\begin{array}{l}\text { Days } \\
\text { required } \\
\text { for emer } \\
\text { gence of } \\
\text { lassel }\end{array}$} \\
\hline & \multicolumn{3}{|c|}{1967} & \multicolumn{3}{|c|}{1969} & \\
\hline & $\begin{array}{l}\text { Date of fower } \\
\text { initialion }^{1}\end{array}$ & $\begin{array}{l}\text { Date of } \\
\text { lassel hip } \\
\text { emergence }\end{array}$ & $\begin{array}{c}\text { Days } \\
\text { required } \\
\text { for emeer- } \\
\text { gence of } \\
\text { tassel }\end{array}$ & $\begin{array}{l}\text { Dale of fower } \\
\text { inilialion }^{2}\end{array}$ & $\begin{array}{l}\text { Dale of first } \\
\text { tassel tip } \\
\text { emergencet }\end{array}$ & $\begin{array}{c}\text { Dayss } \\
\text { required } \\
\text { for emer- } \\
\text { gence of } \\
\text { tossel }\end{array}$ & \\
\hline & & & & & & & Aserage \\
\hline B. 4098 & None & - & 一 & $\begin{array}{c}\text { No material } \\
\text { available }\end{array}$ & - & 一 & 一 \\
\hline B. 49119 & None & 一 & 一 & None & 一 & - & 一 \\
\hline B.0. 17 & Oct. 6 & Dec. 8 & 64 & Sept. 24 & Dec. 6 & 74 & 69.0 \\
\hline B.O. 24 & None & - & - & None & - & - & - \\
\hline Co. 290 & Sept. 25 & Dec. 5 & 72 & Sept. 23 & Nov. 27 & 66 & 69.0 \\
\hline Cl. $41-223$ & Oct. 6 & Dec. 8 & 64 & Oct. 1 & Nov. 26 & 57 & 60.5 \\
\hline H. $41-3340$ & None & - & 一 & Oct. 2 & None & 一 & 一 \\
\hline H. 44-3098 & do & 一 & 一 & None & - & 一 & 一 \\
\hline H. $49-5$ & do & - & - & do & - & - & - \\
\hline H. 49-134 & do & - & - & Sept. 24 & Nov. 26 & 64 & 一 \\
\hline H. $50-2542$ & do & - & - & None & - & - & - \\
\hline H. 50-7209 & do & - & - & Sept. 26 & None & 一 & - \\
\hline H. 51-760 & do & - & - & None & - & 一 & 一 \\
\hline H. 51-4336 & do & - & 一 & do & - & - & 一 \\
\hline H. 52-4610 & do & - & - & do & - & - & - \\
\hline H. 53-263 & do & - & - & do & - & - & - \\
\hline H. 53-1447 & do & - & - & do & - & - & - \\
\hline H. $54-775$ & Sept. 28 & Dec. 4 & 68 & Oct. 1 & Nov. 28 & 59 & 63.5 \\
\hline P.O.J. 3016 & None & - & - & Sept. 25 & None & - & 一 \\
\hline P.R. 1048 & - & - & - & Sept. 25 & Dec. 30 & 97 & - \\
\hline P.R. 1059 & None & - & - & Sept. 24 & None & 一 & - \\
\hline P.R. 1097 & do & 一 & - & Sept. 25 & Dec. 28 & 95 & - \\
\hline R. 397 & Sept. 26 & Nov. 27 & 63 & Sept. 24 & Nov. 25 & 63 & 63.0 \\
\hline Trojan & None & - & - & Sept. 24 & Nov. 20 & 58 & - \\
\hline
\end{tabular}

1 The final observation was made on October 6, 1967.

The final observation was made on October 16, 1969.

8 The final observation was made on January 8, 1970.

As shown in figure 4, some 90 percent of the varieties required 7 to 10 weeks after initiation (2-year average) to produce the first emerging tassel. Variety Tuc. 2683 required least time, ie., 6 weeks for the development and elongation of the inflorescence, while P.R. 1085 required almost 15 
weeks to produce its first visible tassel (table 2). This underscores the distinct time-intervals needed for flower development and elongation among different varieties. Obviously, this is an important factor in determining the flowering time of a given variety.

\section{ENVIRONMENTAL CONDITIONS AFFECTING TIME OF FLOWER INITIATION AND TASSEL EMERGENCE}

The time of flower initiation within respective varieties, as mentioned earlier, tends to be fairly constant from year to year, and it appears to be

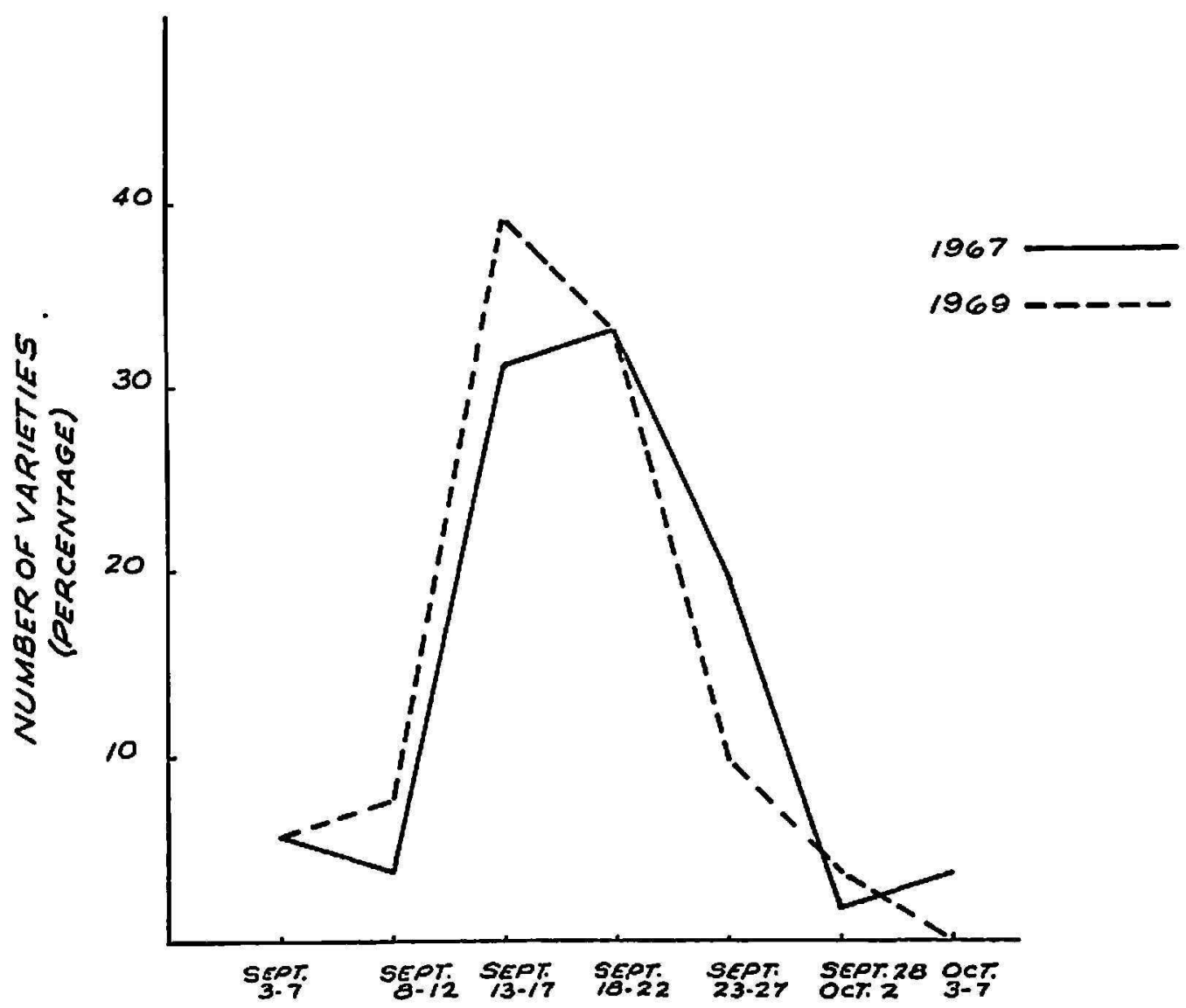

Fra. 2-Frequency distribution of flower initiation date for 51 sugarcane varieties plotted against the number of initiating varieties per each 5-day class interval expressed as a percentage of the total number of varieties.

controlled primarily by photoperiod. The photoperiodic behavior of a given plant, however, may be affected substantially by environmental conditions. The importance of temperature and moisture in controlling sugarcane flowering is well documented $\left(\&, s, \dot{0}, 6^{\prime}\right)$. Meteorological data for the critical months of primordia initiation and inflorescence growth and development are given in table 4.

As shown in figure 2, a majority of the varieties studied in 1969 showed an earlier time of initiation although the photoperiod remained constant each year. A review of temperature records (table 4) shows a lower average 
minimum temperature of $67.6^{\circ} \mathrm{F}$., and especially 12 days of $65^{\circ} \mathrm{F}$. or below temperatures occurring in August and September of 1967, which provides a partial explanation for the differences in time of initiation. In view of the fact that the soil moisture content during August and September of 1969

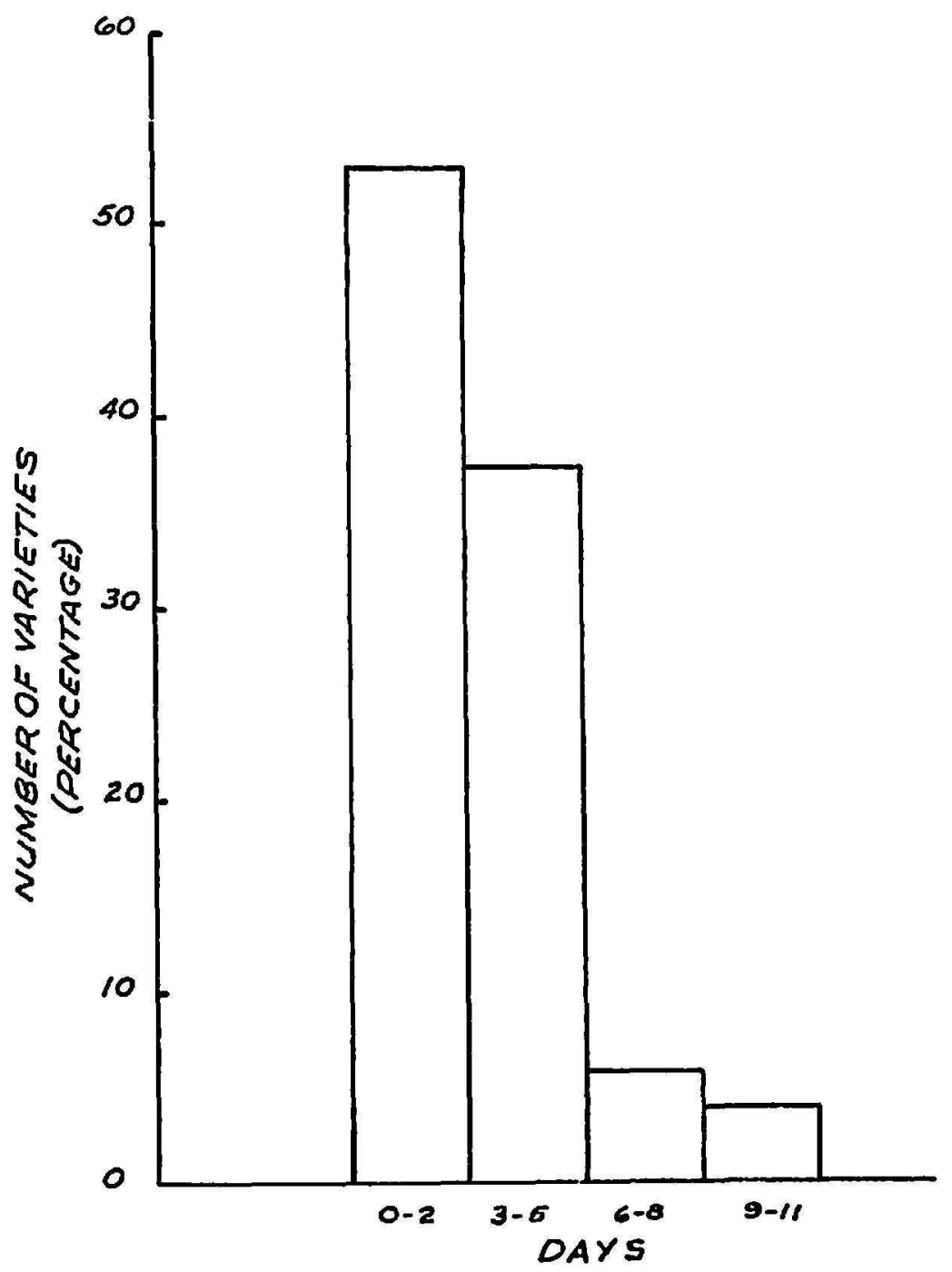

FIa. 3-Frequency distribution of yearly deviation for the flower initiation date of 51 sugarcane varieties plotted against the number of varieties showing deviation in initiation date per each 3-day class interval expressed as a percentages of the total number of varieties.

(table 4) was much higher than during the same period in 1967 (table 4), it seems that soil moisture was an additional factor favoring earlier initiation in 1969 .

From figure 5 it is obvious that a majority of varieties studied in 1969 were significantly earlier in the time of tassel emergence. For instance, C.B. 46-44, Co. 527, Co. 658 and Co. 775 (table 2) advanced the time of tassel emergence by 2 to 3 weeks in 1969, though only slight differences 
( 0 to 3 days) were found in the time of initiation within respective varieties between 1967 and 1969 . The average maximum and minimum temperatures during the critical months for tassel growth and development did not appear to provide the explanation (table 4). A close association was found, however, between the amount of rain and evaporation during the critical period and the behavior of the majority of varieties. The more than double amount

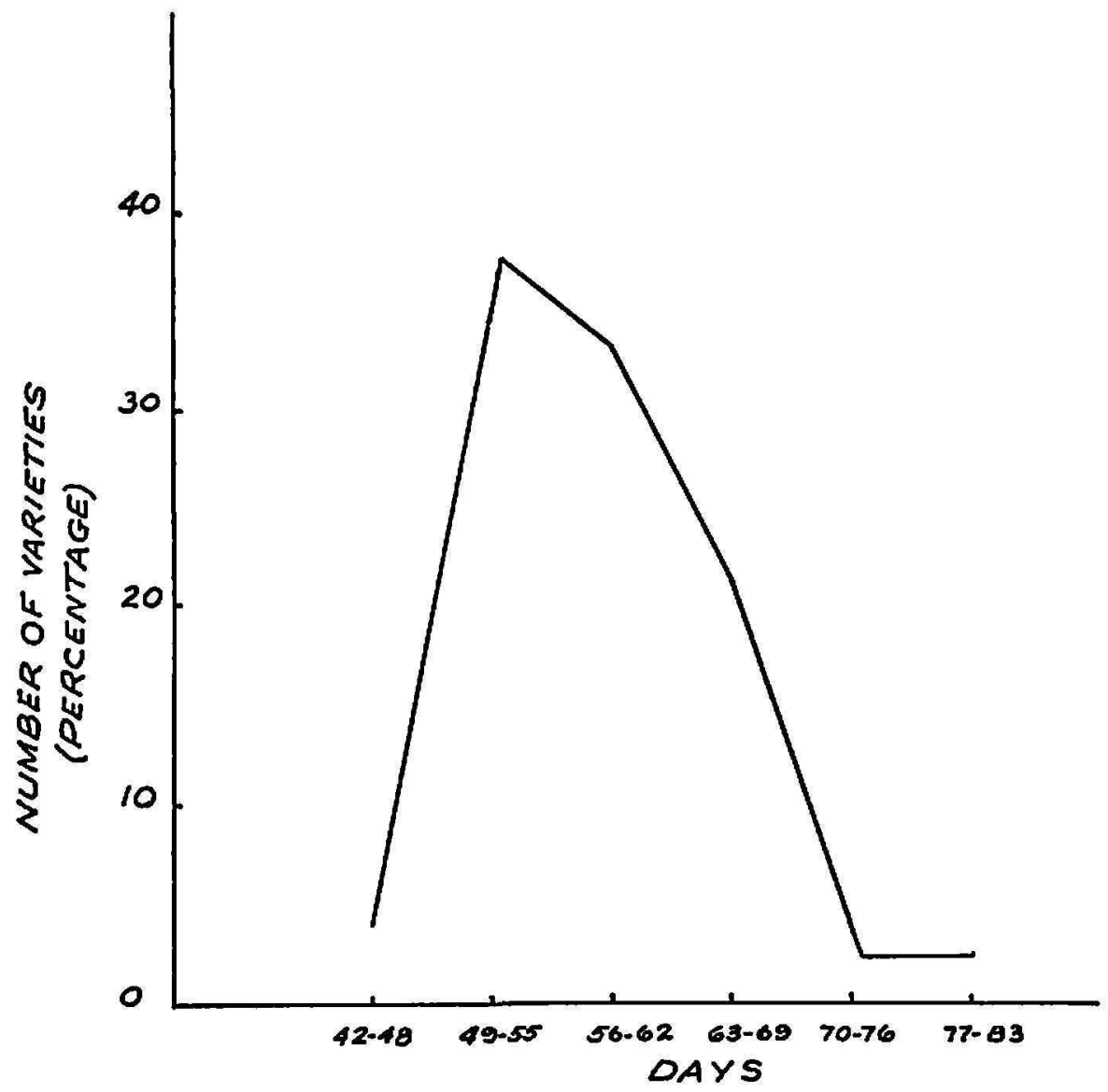

Fig. 4-Frequency distribution of the average number of days required from initiation to first tassel emergence in 51 sugarcane varieties plotted against the number of varieties falling within each class interval expressed as a percentage of the total number of varieties.

of rainfall received during the period of tassel development and elongation in 1969 was likely a major factor causing significant advance in flowering time.

It is possible that faster development and growth of tassels was promoted by the higher soil-moisture and atmospheric-humidity conditions. It should be noted, however, that the effects on both time of initiation and emergence of tassels due to low temperature and moisture stress were not the same for all varieties. Obviously, the sensitivity varies with varieties. 


\section{SUMMARY}

Stem apices of 78 sugarcane varieties were examined microscopically to determine the precise date of flower initiation during the 1967 and 1969 flowering periods at Gurabs Substation, P.R. A stage method for measuring floral initiation was developed and adopted.

It was found that flower initiation or the formation of flower primordia

TABLE 4.-Meteorological data compiled at the Gurabo Agricultural Experiment Substation, 1967 and $1969^{1}$

\begin{tabular}{|c|c|c|c|c|c|c|}
\hline \multirow[b]{2}{*}{ Month } & \multicolumn{3}{|c|}{1967} & \multicolumn{3}{|c|}{1969} \\
\hline & $\underset{\text { Average }}{\text { maximum }}$ & $\underset{\text { minimum }}{\text { Average }}$ & $\begin{array}{c}\text { Number } \\
\text { of days at } \\
5^{\circ} \text {. and } \\
\text { below }\end{array}$ & $\underset{\substack{\text { Average } \\
\text { maximum }}}{c}$ & $\begin{array}{c}\text { Aoerage } \\
\text { minimum }\end{array}$ & $\begin{array}{c}\text { Number } \\
\text { of days af } \\
65^{\circ} \text { o and } \\
\text { belowe }\end{array}$ \\
\hline \multicolumn{7}{|c|}{ Temperalure $\left({ }^{\circ} R.\right)$} \\
\hline August & 89.6 & 67.5 & 9 & 88.5 & 74.3 & 1 \\
\hline September & 89.3 & 67.7 & 3 & 86.2 & 67.5 & 0 \\
\hline (Sub-average) & 89.5 & 67.6 & - & 87.4 & 70.9 & 一 \\
\hline October & 89.6 & 66.7 & - & 88.8 & 68.3 & - \\
\hline November & 86.5 & 66.5 & - & 85.2 & 66.7 & 一 \\
\hline (Sub-average) & 88.1 & 66.6 & 一 & 87.0 & 67.5 & - \\
\hline \multicolumn{7}{|c|}{ Precipitation and evaporation (inches) } \\
\hline Month & \multicolumn{2}{|c|}{ Precipitation } & Evaporation & Precipilation & \multicolumn{2}{|c|}{ Evaporation } \\
\hline August & \multicolumn{2}{|c|}{3.76} & 7.47 & 6.90 & \multicolumn{2}{|r|}{5.42} \\
\hline September & \multicolumn{2}{|c|}{3.09} & 5.66 & 7.26 & \multicolumn{2}{|r|}{$4 . \overline{32}$} \\
\hline (Sub-total) & \multicolumn{2}{|c|}{6.85} & 13.13 & 14.16 & \multicolumn{2}{|r|}{9.74} \\
\hline October & \multicolumn{2}{|c|}{3.57} & 5.49 & 4.71 & \multicolumn{2}{|r|}{5.14} \\
\hline November & \multicolumn{2}{|c|}{4.37} & 4.06 & 12.03 & \multicolumn{2}{|r|}{3.82} \\
\hline (Sub-total) & \multicolumn{2}{|c|}{7.94} & 9.55 & 16.74 & \multicolumn{2}{|r|}{8.96} \\
\hline Total & \multicolumn{2}{|c|}{14.79} & 22.68 & 30.90 & \multicolumn{2}{|r|}{18.70} \\
\hline
\end{tabular}

1 U.S. Weather Bureau report.

is not simultaneous among all varieties of sugarcane. Initiation time was found to vary from September 1 to September 30. The model day-length for floral initiation in Puerto Rico (latitude $18^{\circ} \mathrm{N}$.) appears to be 12 hours, 7 to 17 minutes.

Both time of initiation and speed of inflorescence growth and development was found to be related to the time of flowering.

The time required for the development and elongation of inflorescences was from 7 to 10 weeks in 90 percent of the varieties. 
The time of initiation in respective varieties is fairly constant from one year to the next. This indicates that flower initiation in sugarcane is determined primarily by photoperiod. However, as indicated in these studies, both low temperature and moisture stress were regarded as important factors in delaying the time of flower initiation. Moisture stress during 1967 appeared to be the predominant factor causing significant delay in the time of tassel emergence among the majority of varieties studied.

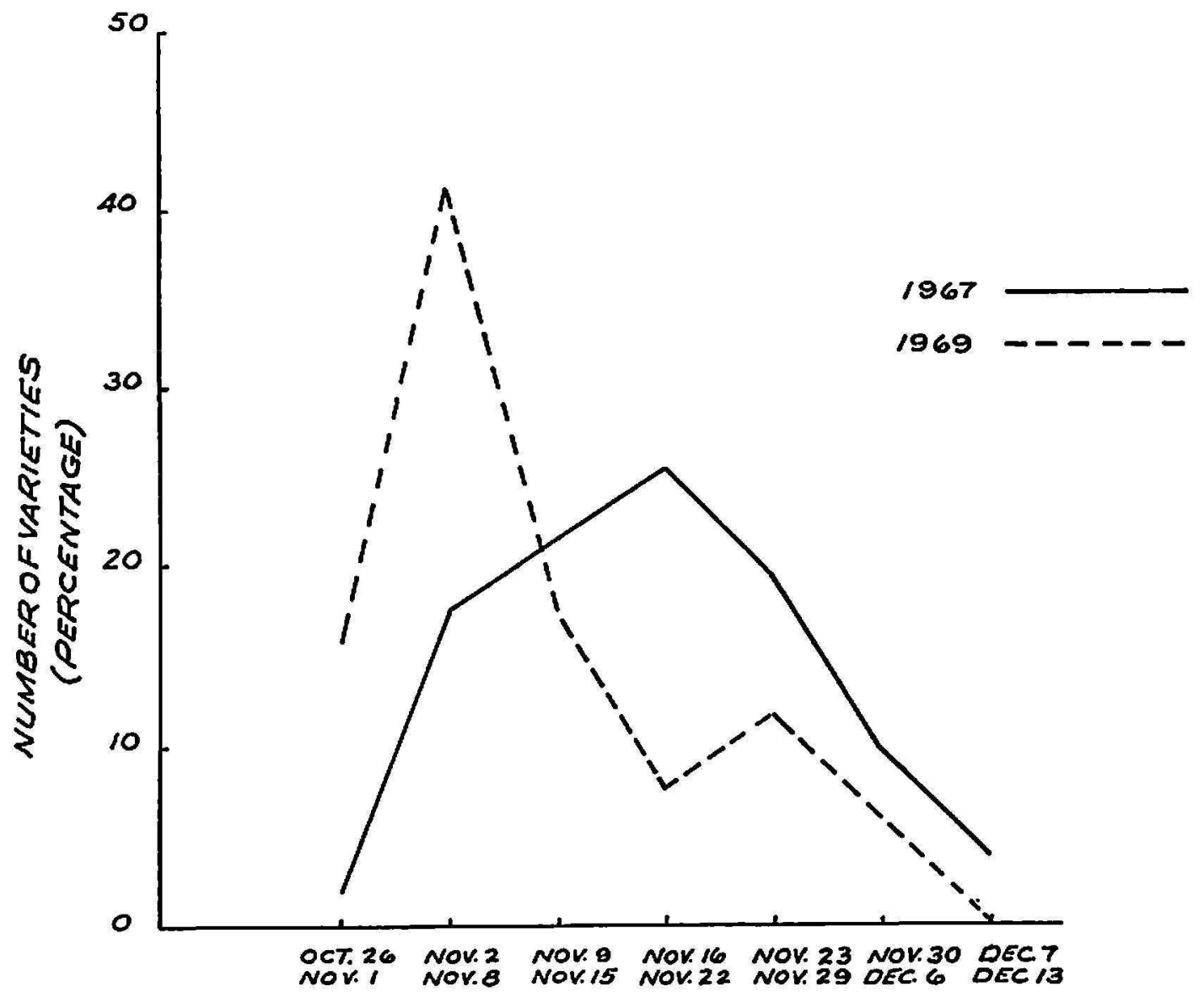

Fra. 5-Frequency distribution of first tassel tips emergence date for 51 sugarcane varieties plotted against the number of varieties emerging first tassel per each 7-day class interval expressed as a percentage of the total number of varieties.

\section{RESUMEN}

Durante los períodos de floración de la caña de azúcar del 1967 y 1969, en la Subestación de Gurabo, Puerto Rico (latitud $18^{\circ}$ N.) se examinaron bajo el microscopio los ápices de 78 variedades con el fin de determinar la fecha exacta en que se inicia la formación de los primordios florales. Para determinar el progreso de este proceso se desarrolló un sistema de grados o etapas.

Se descubrió que la fecha en que comienzan a formarse los primordios florales cambia de una a otra. En las variedades que se estudiaron, las 
fechas variaron durante todo un mes, desde el 1 hasta el 30 de septiembre. El mayor numero de variedades inició la formación de los primordios florales en los días cuya duración varía de 12 horas 7 minutos a 12 horas 17 minutos.

Tanto la formación de los primordios como la rapidez con que se desarrolla y crece la inflorescencia están relacionados con la fecha de la floración.

En 90 por ciento de las variedades que se estudiaron el intervalo que media entre la formación de los primordios florales y el desarrollo de la inflorescencia fue de 7 a 10 semanas.

Para las variedades estudiadas la fecha en que comienzan a formarse los primordios florales es más o menos la misma de uno a otro año, lo cual demuestra que el inicio de la floración está regido primordialmente por el fotoperíodo. No obstante, es posible que las temperaturas bajas, como también la relativa escasez de humedad, sean factores causales de demoras en el inicio de la floración. A este respecto, tai parece que en 1967 el retraso en el brote de la inflorescencia en la mayor parte de las variedades se debió a la menor cantidad de lluvia que cayó en ese año.

\section{LITERATURE CITED}

1. Burr, G. O., Hartt, C. E., Brodie, H. W., Tanimoto, T., Kortschak, H. P., Takahashi, D., Ashton, F. M., and Coleman, R. E., The sugareane plant, Ann. Rev. Plant Physiol. 8: 275-308, 1957.

2. Chu, T. I., and Serapión, J. L., Effect of certain climatic factors on flowering of sugarcane at Gurabo, Puerto Rico, J. Agr. Univ. P.R. 58(4): 221-29, 1969.

3. Clements, H. F., and Awad, M., Factors affecting the flowering of sugarcane, Ind. J. Sugarcane Res. Dev. 8: 140-59, 1964.

4. Coleman, R. E., Factors involved in the flowering of sugarcane (S. spp.) (Thesis) 1956, Univ. Haw. Library, (quoted from Clements, et al., 1964).

5. - - Effect of temperature on flowering in sugarcane, Int. Sugar J. 65: 351-53, 1963.

6. - Physiology of flowering in sugarcane, Proc. Int. Soc. Sugarcane Technol. 1s: 992-1,000, 1968.

7. Lan, A., Physiology of flower initiation, Encyclopedia Plant Physiol. 15: 1,380$536,1965$.

8. Lincoln, E. H., Raven, K. A., and Hamner, K. C., Certain factors influencing expression of the flowering stimulus in Xanthium. I. Translocation and inhibition of the flowering stimulus, Bot. Gaz. 117: 193-206, 1956.

9. Paliatseas, E. D., and Chilton, S. J. P., The induction of the emergence of the inflorescence of sugarcane, Proc. Int. Soc. Sugarcane Technol. 9: 657-64, 1956.

10. Panje, R. R., and Srinivasan, K., Studies in Saccharum spontaneum. A note on the flowering sequence of $S$. spontaneum clones, Proc. Int. Soc. Sugarcane Technol. 10: 819-24, 1959.

11. Purvis, 0 . N., An analysis of the influence of temperature during germination on the subsequent development of certain winter cereals and its relation to length of day, Ann. Bot. 48: 919-54, 1934. 
12. Salisbury, F. B., Photoperiodism and the flowering process, Ann. Rev. Plant Physiol. 12: 293-326, 1961.

13. Stevenson, G. C., Genetics and breeding of sugarcane, Longmans, Green and Co., Ltd., London, England, p. 81, 1965.

14. Vijayasaradhy, M., and Narasimhan, R., Control of flowering in sugarcane, Proc. Int. Soc. Sugarcane Technol. 8: 371-401, 1953. 